\title{
PREVALENCE OF FOOT AND MOUTH DISEASE AT CHUADANGA SADAR UPAZILLA IN BANGLADESH
}

\author{
M. G. Sorwar ${ }^{1 *}$, M. A. $\operatorname{Rahman}^{1}$, M. N. Hasan ${ }^{1}$, S. Hossain ${ }^{1}$ and S. M. S. Islam ${ }^{2}$ \\ ${ }^{1}$ Department of Medicine, Surgery and Obstetrics, Faculty of Animal Science and Veterinary Medicine, \\ Patuakhali Science and Technology University, Dumki-8602, Patuakhali, Bangladesh; ${ }^{2}$ Upazilla Veterinary \\ Hospital, Chuadanga Sadar, Bangladesh
}

\begin{abstract}
A study on clinical observation, management and complication of foot and mouth disease (FMD) outbreak in cattle was carried out in Chuadanga sadar upazilla during 24 weeks period from July 2012 to January 2013. Clinical data were collected from 108 cattle of both sexes. The effect of season, breed, age, sex and purpose of keeping cattle on the incidence of the disease was analyzed. Seasonal variation of the disease was significant. Crossbred was found to be more susceptible than local breed. The prevalence of the disease was found significantly higher in male than female. The clinical prevalence of FMD increased in the month of November $(31.48 \%)$. The prevalence of FMD in other months varies from 5-21\%. Clinical observation of FMD affected cattle showed fever, anorexia, salivation and erosive lesion on oral mucosa and inter digital region of foot. Antibacterial drug could be recommended for clinical practice to control secondary bacterial infection in complicated FMD cases.
\end{abstract}

Key words: Foot and mouth diseases (FMD), prevalence, Bangladesh

INTRODUCTION

Foot and mouth disease (FMD) is a highly contagious viral disease of cloven footed domestic and wild animals such as cattle, buffaloes, yaks, sheep, goats, and swine. Other susceptible species are hedgehogs, armadillos, nutrias, elephants, capybaras, rats and mice. Camels, dromedaries and llama have low susceptibility. Horses are not susceptible to FMD and humans are affected only vary rarely (Samuel and Knowles, 2001). The causal agent is a small, non-enveloped, single stranded RNA virus. It is a member of genus aphthovirus in the family Picornaviridae. Seven immunologically distinct serotypes are recognized- A, O, C, Asia-1, South African Territories (SAT-1, SAT-2 and SAT-3). It is prevalent in Bangladesh with virus types A, O, C, Asia-1 and subtypes A-5 and A-22 (Khan et al., 2002; Loth et al., 2011). FMD appears in cattle of Bangladesh either generally in endemic or sometime in epidemic form. Amongst the livestock diseases FMD is thought to be most dreadful one owing to its fierce pathogenicity and complexity in controlling it. Once the outbreak starts, it continues round the year affecting large number of cattle herd. The incidence of the disease was recorded highest in 1990. Out of 64 districts FMD epidemic was broken out in 55. During that period the economic loss was disastrous due to all out production loss of cattle by the outbreak of FMD (Ali et al., 2011). An average of 130 incidents (outbreak) of FMD every year has been reported from Bangladesh (Domingo et al., 2002). Howlader $e t$ al. (2004) estimated an economic loss of taka 4168.4 thousand for 4750 FMD affected cattle and recorded $61.2 \%$ prevalence in cattle and $19.5 \%$ calf mortality due to this disease in Bangladesh. On the basis of the above circumstances the objective of this study was to determine FMD infection in terms of age, sex and breed. Evaluation of comparative efficacy of different antibacterial drugs on the course of disease healing of FMD lesions and complications of FMD infections will also be studied. This paper justifies the economic impact of FMD including how it varies in different settings and how knowledge of this should be used to guide control policy. This included a synthesis of current literature on the subject. To help appreciate the scale of global FMD impact estimates were made of the direct costs of disease and vaccination in endemic countries as well as outbreak costs in free countries. The findings of this study also emphasis the formulation of more effective disease management and control strategies, including appropriate vaccination policies in Bangladesh.

*Corresponding e-mail address: sorwargs@gmail.com 


\section{G. Sorwar and others}

\section{MATERIALS AND METHODS}

The study was conducted in the upazilla veterinary hospital, Chuadanga, during the period from July 2012 to January 2013. A total of 108 cattle suffering with skin disease were examined. A pre-set questionnaire was filled containing various types of information regarding to age, sex, breed, management, previous disease and preventive measures during examination. The field diagnosis of this disease was confirmed based on clinical history collected from owner and clinical findings of the affected cattle according to Rahman et al. (2012). Inspection, palpation, percussion and auscultation methods were used to examine the affected animal. To identify the case the following clinical signs were observed carefully such as high fever $\left(104-106^{\circ} \mathrm{F}\right)$, nasal discharge, salivation, lesion on the dorsal surface of the tongue, foot lesion in the interdigital region. Secondary bacterial complication of FMD lesion may interfere with healing and lead to severe involvement of the deep structure especially the foot. Severely FMD affected cases were treated with antimicrobial drugs to control secondary bacterial infections. Some commercial antimicrobial drugs were used to evaluate for the management of clinical case of FMD (OIE, 2004).

\section{Statistical analysis}

Data were analyzed by chi-square test to observe the significant influence of different seasons, sex, age and breeds on the disease using Statistical Package for Social Science, SPSS Version 13.0 (Coakes et al., 2006).

\section{RESULTS AND DISCUSSION}

The monthly variation of FMD infection is shown in Table 1. The mean monthly variation during the period was satisfactory significant. It reveals that the most of the animal affected with FMD was in the November.

Table 1: Prevalence of FMD at different seasons

\begin{tabular}{lllc}
\hline Name of the Months & No of affected cattle & Percentage (\%) & Chi square Test (P-value) \\
\hline July, 2012 & 6 & 5.56 & $0.000^{* *}$ \\
August, 2012 & 23 & 21.30 & \\
September, 2012 & 8 & 7.40 & \\
October, 2012 & 15 & 13.89 & \\
November, 2012 & 34 & 31.48 & \\
December, 2012 & 15 & 13.89 \\
January, 2013 & 7 & 6.48 & \\
\hline Total & 108 & 100 & \\
** Significant at $\mathrm{p}<0.01$ & &
\end{tabular}

It is seen that the infection is higher in November (31.48\%). Melo et al. (2003) found that FMD prevalence highest in November (35.59\%) and December (37.14\%) in Rajshahi.

Table 2. Prevalence of FMD at different sex, age and breeds

\begin{tabular}{|c|c|c|c|c|c|c|}
\hline \multirow[t]{2}{*}{ Breed of cattle } & \multirow[t]{2}{*}{ Animal infected } & \multicolumn{2}{|c|}{ Sex variation } & \multicolumn{2}{|c|}{ Age variation } & $\begin{array}{l}\text { Chi square Test (P- } \\
\text { value) }\end{array}$ \\
\hline & & Male & Female & Young & Adult & $0.000 * *$ \\
\hline Local & $41(38 \%)$ & $26(63 \%)$ & $15(37 \%)$ & $7(17 \%)$ & $34(83 \%)$ & \\
\hline Crossbred & $67(62 \%)$ & $42(63 \%)$ & $25(37 \%)$ & $13(19 \%)$ & $54(81 \%)$ & \\
\hline
\end{tabular}

** Significant at $\mathrm{p}<0.01$

It is observed that cross-bred are more susceptible than local breed. It is supported by (Melo et al., 2003). Male and adults are more susceptible than young. It is supported by (Rahman et al., 2012). Thus in case of FMD vaccine crossbred animal may get the priority of vaccination. 
Table 3. Prevalence of FMD in Chuadanga sadar

Prevalence of foot and mouth disease

\begin{tabular}{llllc}
\hline Cattle & No of animal & Affected & Prevalence $(\%)$ & Chi square Test (P-value) \\
\hline Bull and Bullock & 175 & 60 & 34.28 & $0.000^{* *}$ \\
Cow & 90 & 28 & 31.11 & \\
Calf & 67 & 20 & 29.85 & \\
\hline Total & 332 & 108 & 32.53 & \\
\hline
\end{tabular}

** Significant at $\mathrm{p}<0.01$

The prevalence of FMD in bull was $34.28 \%, 31.11 \%$ in cow and $29.85 \%$ in calf (Table 3). The total prevalence rate is 32.53\%.It is slight different from Melo et al. (2003) where they found 25.07\% FMD in Rajshahi. The first clinical sign in FMD affected cattle are pyrexia, lassitude and anorexia. Vesicle appeared on the oral mucosa especially on the tongue, and then the interdigital space of the feet. At his clinical picture resemble very closely to those described by (Samuel and Knowles, 2001).Although a marked reduction of milk production and loss of working ability of the FMD infected cattle were recorded during the study. However the economic loss of FMD due to calf mortality, reduce milk yield and plough loss are also found.

In uncomplicated cases the FMD lesion usually healed within 12 days either by gradual replacement of the epithelium or after scab formation, but in complicated case secondary bacterial infection occurs. The course of the disease varied from 14-21 days even more. The observation supports the findings of Domingo et al. (2002) who reported that FMD affected cattle suffered for a period of 12-22 days.

The FMD affected clinical cases complicated with secondary bacterial infection were treated with different anti-bacterial drug to evaluate their comparative efficacy on the course of the disease with healing of FMD lesion (Table 4). The sulphadimidine require 7-8 days, ampicillin required 8-9 days and oxytetracycline required 10-11 days to heal up the lesion. Although sulphadimidine injection was found more effective to control the secondary bacterial infections and healing of FMD lesion. But this entire drug was found to have a significant effect for healing of FMD lesions in comparison to infected cattle. Madhanmohan et al. (2009) reported that cattle fed with zinc sulphate have more antiviral activity and Gleenson et al. (2003) reported that cattle fed with green treated with caustic soda found to have some activity against FMD virus. No record of FMD infection was observed in vaccinated animal during 16 weeks of period, which is an indication of the effectiveness of vaccination. However, control of FMD in endemic country like Bangladesh can be achieved by vaccination and controlling management should be taken (OIE, 2004).

Table 4. Evaluation of antibacterial drugs against secondary bacterial infection in FMD

\begin{tabular}{llll}
\hline Drugs used & Dose and route of administration & $\begin{array}{l}\text { Complete healing of foot } \\
\text { lesion range (mean) days }\end{array}$ & $\begin{array}{c}\text { Chi square Test } \\
(\mathrm{P}-\mathrm{value})\end{array}$ \\
\hline Sulphadimidine & $\begin{array}{l}25 \mathrm{ml} / 50 \mathrm{~kg} \text { body weight } \\
\text { IM daily for 5 days }\end{array}$ & $7-8(7.5)$ & $0.000^{* *}$ \\
Ampicillin & $\begin{array}{l}12 \mathrm{ml} / 100 \mathrm{~kg} \text { body weight } \\
\mathrm{IM} \text { daily for 5 days }\end{array}$ & $8-9(8.5)$ \\
Oxytetracycline & $\begin{array}{l}12 \mathrm{ml} / 100 \mathrm{~kg} \text { body weight } \\
\text { IM daily for 5 days }\end{array}$ & $10-11(10.5)$ \\
\hline
\end{tabular}

** Significant at $\mathrm{p}<0.01$

\section{CONCLUSION}

It could be concluded that cross-bred males are more susceptible than local breed. The prevalence of disease was found higher in adults than young. Seasonal variation of the disease was remarkable. The most animals affected with FMD were in rainy season, winter and during livestock marketing. A large number of cattle died of FMD and the financial loss incurred from this mortality. The economic losses due to calf mortality, reduced milk 


\section{G. Sorwar and others}

yield, draft power and poor body weight gain of fattening bull was seen. FMD is a fatal viral disease and causes severe economic loss of our country. Moreover, it has no specific treatment. So, vaccination is the only way to prevent the disease. Emphasis on vaccination should be given by the government and farmer also. Mutagenic change can occur thus vaccine production should be done by collecting sample from the field. If proper preventive measure can be taken we can reduce the economic loss caused by FMD.

\section{REFERENCES}

1. Ali MH, Bhuiyan MKJ and Alam MM (2011). Retrospective epidemiologic study of diseases in ruminants in Khagrachari Hill Tract District of Bangladesh. Bangladesh Journal of Veterinary Medicine 9: 145-153.

2. Coakes SJ, Steed L and Dzidic P (2006). SPSS Version 13.0 for Windows. John Willey and Sons Australia Ltd., Australia.

3. Domingo E, Baranowski E and Escarmis S (2002). Foot and mouth disease. Microbiology and Infectious Diseases 25: 297-308.

4. Gleenson LJ, Bauer K and Aidaros HA (2003). A review of the status of FMD in South East Asia and approach to control and eradication. Science and Technology Review 21: 465-475.

5. Howlader MMR, Mahbub-E-Elahi ATM, Habib S, Bhuyian MJU, Siddique MAB, Hai MA and Hossain MG (2004). Foot and mouth disease in Baghabari milk shed area and its economic loss in Bangladesh. Journal of Biological Science 4: 581 583.

6. Khan S, Geale DW and Kitching P (2002). Duncan vaccination against FMD: the implication for Canada. The Canadian Veterinary Journal 45: 349-354.

7. Loth L, Osmani MG, Kalam MA, Chakraborty RK, Wadsworth J, Knowles NJ, Hammond JM and Benigno C (2011). Molecular characterization of foot and mouth disease virus; implications for disease control in Bangladesh. Transboundary and Emerging Diseases 58: 240-246.

8. Madhanmohan M, Tresamol PV and Saseendranath MR (2009). Immune response in goats to two commercial foot and mouth disease vaccines and the assessment of material immunity in their kids. Transboundary and Emerging Diseases 56: 49-53.

9. Melo E, Correa, Saravia V and Astudillo V (2003). A review of the FMD in countries of South Asia. Science and Technology Review 21: 429-436.

10. OIE (2004). Principles of Veterinary Vaccine Production. In: Manual of Diagnostic Tests and Vaccines for Terrestrial Animals. Version adopted May 2006. Chapter 1: 1.7.

11. Rahman MA, Islam MA, Rahman MA, Talukder AK, Parvin MS and Islam MT (2012). Clinical diseases of ruminants recorded at the Patuakhali Science and Technology University Veterinary Clinic. Bangladesh Journal of Veterinary Medicine 10: 63-73.

12. Samuel AR and Knowles NJ (2001). Diagnosis of different types of FMD virus in Ethiopia. Journal of General Virology 82: 609-621. 